\title{
Sino-Turkish Strategic Economic Relationship in New Era
}

\section{Zhiqiang Zou*}

\begin{abstract}
:
This article argues that the dynamic development of Sino-Turkish economic relations has got new strategic significance amid rising of the two countries in the $21^{\text {st }}$ century. The strategic significance of Turkey economy to China lies in the following aspects: there is great economic cooperative potential between the two countries in view of economic power and momentum; as the principle members of emerging powers, both of them have growing common interests in global economic transformation and governance reform; Turkey plays an increasing important role in evolution of Eurasian geo-economic structure as well as the Silk Road Economic Belt construction. There are fruitful strategic contents for Sino-Turkish economic relationship in new era; bright prospects can be predicted in bilateral cooperation in aspects including trade, investment, finance and global economic governance. Look ahead, China should pay more attention to Turkey's importance and make great efforts to build bilateral strategic economic relationship.
\end{abstract}

Keywords: $\quad$ China; Turkey; Rise; Strategic Economic Relationship

* Correspondence Address: Zhiqiang Zou, The Middle East Studies Institute, Shanghai International Studies University, 550 Dalian Road(W), Shanghai, 200083, China. Email: zzq8585@163.com 


\section{Introduction}

Turkey locates at the geopolitical and civilization intersection in Eurasia. Multiple historical heritage of Ottoman Empire can be found throughout the rising process of Turkey. Turkey's multiple identities, as a member of OECD and NOTO, a Middle East country, an Islamic country, a Turkic power as well as an emerging power, has inspired it to rise. In recent years, meanwhile, continued economic prosperity, political stability and rising international status of Turkey enhance its confidence of rising. Turkey locates across Europe and Asia, The level of its land area, population size and economic scale is as big as a medium large country. The degree of Turkey's modernization is quite advanced, the speed of its economic growth is fast, and its development is promising. Turkish economy is market-oriented and outward. Its pursuit of joining in the European Union has greatly improved its market-oriented and outward degree, making it an important gathering place for global capital. Turkey has long been among the regional countries with representativeness and influence in the Middle East region and the Islamic world, making it have a strong position in many regions such as the Middle East, the Balkans and Central Asia. Present day, the global economic pattern and economic governance are undergoing continuous and deep transition. In this process, Turkey has shown its global influence and systemic importance. Since the financial crisis, the importance of G20 in global economic governance has also promoted Turkey to stand on the front of the global economic governance. Turkey had taken the presidency of the G20 at the end of last year, The G20 summit will be held in November in Antalya. Turkey will hand over the presidency of G20 to China in 2016. As a special country which has multiple statuses, like a member of OECD and an emerging power, Turkey's position is increasingly important in global economic affairs and governance.

In recent years, the relationship between China and Turkey has drawn attention and hot discussion from the academic circles in both countries, for the reason that both China and Turkey have raised rapidly on regional and global level, and both of them would like to hear from the other. ${ }^{1}$ It is of great practical significance to understand the peaceful development and rise of Turkey and China. Turkey has viewed China as its important opportunity for rapid development. ${ }^{2}$ However, there is certain gap and dislocation on their strategic cognition on the other. China attaches more importance to Turkey's strategic value on security level while China's importance is economic from Turkish perspective. Just like China's rise, Turkey's rise has also been focused by scholars and many research fruits have been made in this regard, but there's still lack of the analysis on the connections of the rises between the two. Against the transition era of global economic pattern and the Eurasian geo-economic pattern, both China and Turkey are in rising process in which their foreign economic relationships are also undergoing great changes. Both sides' strategic and economic importance is increasing to the other, and their cognition and policies toward the other are also adjusting and repositioning. As a member of G20 and a rapid developing emerging power, Turkey's advantage in its strategic economic position is very outstanding. It is an important cooperative partner to China. In new era, there is huge potential in strategic content of the economic relationship between China and Turkey. In the future, Turkey will play an outstanding role in China's foreign economic relationships. Sino-Turkish strategic economic relationship is worth deep and systematic analysis. 


\section{Turkish Economy and Development of Sino-Turkish Economic Relationship}

While Turkey has undergone tremendous domestic change in the past decade, an arguably more significant shift is its emergence as an economic power. ${ }^{3}$ Since the taking power of Turkish Justice and Development Party, Turkish economy has made the "miracle" of continuing economic development. The growth rate of its economy has kept in high level and has even exceed 8 percent, marking Turkey the country with fastest growing and strongest momentum in Europe and the Middle East. ${ }^{4}$ The rank of the total economy of Turkey has move forward from 26 to 17 . Its economic development has attracted worldwide attention, at the same time, its international economic position has also been dramatically improved. Turkey's role can be seen and even become more obvious in economic cooperation, coordination and governance on regional and global stage. According to the data of Turkish Statistical Institute, GDP of Turkey has increased from $\$ 230.5$ billion in 2002 to $\$ 821.9$ billion in 2013. Over the same period, per capital GDP of it has soared from $\$ 3,492$ to $\$ 10,782$. $^{5}$ The scale of Turkey's foreign trade has also increased. Foreign trade volume has increased from $\$ 87.6$ billion in 2002 to $\$ 403.5$ billion in 2013 . Dependence on foreign trade has undergone improvement. In 2012, Turkey's dependence on foreign trade achieved 54 percent. ${ }^{6}$ Meanwhile, Turkey also faces continued trade deficit and growing foreign trade frictions. The trade deficit of Turkey was $\$ 105.8$ billion, $\$ 84.1$ billion and $\$ 99.8$ billion respectively in 2011, 2012 and 2013, accounting 20 to 30 percent of its foreign trade volume. ${ }^{7}$ Viewing from the geographical distribution of Turkey's foreign economic relationship, European countries were the main economic and trade partners of Turkey, but their importance is declining; surrounding countries also have important influence on Turkish foreign economic relationship, especially on energy related fields; Asia Pacific and other emerging countries are new economic partners of Turkey and their importance is increasing.

The development of economic strength also improves Turkish people's national pride and self-confidence, letting them to have more awareness as a power and global ambitions. At the same time, Turkey's economic demands have also expanded and its international economic position has been enhanced. Its membership in G20 highlights its International status as a power. Its own demand for participating in global economic cooperation and governance also increases gradually. Turkey has attached more importance to global development issues and put more efforts in foreign aid. According to the statistics of OECD, ODA of Turkey in 2010 was $\$ 967$ million, ${ }^{8}$ making Turkey an emerging donor. In 2008, Turkey established strategic partnership with the African Union and joined African Development Bank, the first Turkey-Africa Summit was held in Istanbul; at the same year, Ministerial Conference of Turkish-Arab Cooperation Forum was held, which shows that Turkey tries to play a role as a global economic power as China. As an emerging power as well as a rapid growing economy, Turkey's diplomacy is increasingly active. It will be among the countries that get most focus from the world. ${ }^{9}$

Viewing from the economic relationship between China and Turkey, in the new century, the trade and economic bilateral relationship has been on the rapid-developing track. Turkey has been among China's important economic partners. Since 2005, Turkey has promoted its economic development policies toward China in full fields. Turkish Ministry of Economy has carried out programs targeting to promote Chinese market. ${ }^{10}$ Turkey and China have been viewed as the two most rapid growing economies in G20. The development momentum of bilateral economic and trade relationship is quite strong. In 2010, Wen Jiabao, then Chinese premier, visited Turkey, 
during which China and Turkey announced to establish strategic cooperative relationship. Chinese leaders expressed that they have already realized Turkey's strength and its influence in international community and its surrounding regions. Both sides have signed many agreements and decided to settle the trade by currency of the two countries. They planed to increase bilateral trade volume from $\mathrm{m} \$ 17$ billion in 2010 to $\$ 50$ billion in 2015, and to 100 billion in 2020. In | 16 February 2012, then vice president Xi Jinping visited Turkey. During his visit, central banks of the two formally signed the currency swap agreement. Turkey became the $16^{\text {th }}$ country who has signed currency swap agreement with China. In April 2012, Turkish Prime Minister Recep Tayyip Erdogan led a delegation with 300 businessmen to visit China, aiming to promote economic and trade cooperation. Both sides have signed a serious of economic and trade cooperative agreements covering fields including nuclear energy.

The interaction between China and Turkey is growing close. China has already been the important trade partner of Turkey. The data of China Customs shows that from 2001 to 2013, the trade volume between China and Turkey has jumped from $\$ 900$ million to $\$ 22.2$ billion; China has maintained the trade surplus. According to the data of Turkish Statistical Institute, from 2004 to 2013, bilateral trade volume has increased from $\$ 4.8$ billion to $\$ 28.3$ billion, Turkey has kept the trade deficit. The proportion of Turkey's trade deficit to China in its total deficit increased from 11.8 percent in 2004 to 21.1 percent in 2013. In 2009, this proportion was as high as 28.5 percent. China is the third trade partner of Turkey (follow Germany and Russia) and the $11^{\text {th }}$ biggest exporting market as well as the second source of imports (after Russia); China's proportion in Turkish total export volume has increased gradually from 0.6 percent in 2004 to 2.4 percent in 2013. During the same period, China's proportion in Turkish total import volume has also increased rapidly from 4.6 percent to 9.8 percent. ${ }^{11}$ However, due to the limited trade volume, Turkey ranks more than 30 in China's trade partners.

In recent years, mutual investment between China and Turkey is not very huge, and the speed of growing is not very stable. China's investment to Turkey covers transportation, shipping, energy, communication, trade, travel and so on. Two sides have already made some achievements in project contracting, which has become the highlights of the economic and trade cooperation between the two. China's non-financial investment to Turkey has increased from \$5.31 million in 2008 to $\$ 194$ million in 2013. In 2009, this number was as high as $\$ 300$ million. During the same period, Turkey's investment to China has increased from $\$ 7.29$ million to $\$ 40.04$ million. Completed project contracting amount has increased from $\$ 810$ million to $\$ 1.94$ billion. ${ }^{12}$ Gong Xiaosheng, former Chinese ambassador to Turkey, described the cooperation on economics, trade and investment between China and Turkey as "overwhelming", meaning that the cooperation has covered many fields including manufacturing and launch of satellites, aviation, railways, highways, steel, power plants and mining. Besides, tourists from China to Turkey have been exceeded 120,000 people. Generally speaking, although the present-day scale of the interaction between China and Turkey is not very big, it has already shown an upward momentum and become the important foundation of the development of the bilateral relationship between the two. 


\section{Strategic Contents of Economic Sino-Turkish Relationship in New Era}

As the name suggests, strategic economic relationship means that the economic relationship is strategic. Provided the huge changes in global economic pattern and China's international position, bilateral strategic economic relationship exists not only among powers and power groups, but also among economic relationships among emerging powers and regional powers. Viewing from the scale of the bilateral relationships, the economic relationship between China and Turkey is far from strategic. However, Turkey is of more strategic importance in economic regard. On many levels including bilateral, Middle East, Eurasia and global level, in many fields such as trade, investment, finance, regional economic cooperation and global economic governance, both sides have strategic value and space for cooperation, which is promising.

Economic strength and development trend create great potential for bilateral economic cooperation and make it growing strategic.

In recent decades, Turkey has been among the most rapid developing countries. Its total economy is expanding and the scale of economy has been doubled. It has been the $17^{\text {th }}$ biggest economy in the world and the biggest in the Middle East, as well as the $6^{\text {th }}$ biggest in Europe. The increasing speed of the development of Turkey's foreign trade is even faster, the scale of which is 2.5 times of it was in the previous year. In 2012, it ranks 22 and 15 on export and import in the world. At the same time, the population is more than 76 million in Turkey and per capital income of them is more than $\$ 10,000$. Urbanization and modernization are quite advanced in regions more than the Middle East. Turkey also has rich human resources, and advantages in trade and investment. It is among the important global investment markets and emerging consuming markets. The outstanding performance of Turkish economics has drawn global attention, and has been described as the "Anatolian tiger". ${ }^{13}$ With its great developing potential, high-quality labors and managers teams, coupled with its entrepreneurial spirit, Turkey has been an important potential market for international business. It will be the most likely engine for the economic development of Balkans, the Caspian Sea, Central Asia and the Middle East. ${ }^{14}$ Development of economic strength also promotes Turkey's awareness as a power and its global ambitious. Turkish government plans to become the global top 10 in 2023 when the $100^{\text {th }}$ anniversary of the country is marked and become an influential power. Turkish leaders have also expressed that Turkey would be the second economy following Germany in Europe.

Although the trade and economic cooperation between China and Turkey has maintained the upward momentum, current trade volume has not fully reflected the potential between the two. 15 In 2012, Turkey listed China as a main exporting target. Given the economic scale, development momentum, economic complementarity and importance in the world, there is great potential of the economic cooperation between China and Turkey. At the same time, both China and Turkey have strong wills of expanding economic and trade cooperation. Two countries have complementarity in many fields including finance, technology and markets. On bilateral and multilateral levels, cooperation is promising in trade, investment, finance, transportation infrastructure, energy and channel construction, overseas projects contracting and tourism. 
As two emerging countries, China and Turkey have more cooperation on global economic governance and transitions.

As the $17^{\text {th }}$ biggest economy in the world and a member of G20, Turkey is an important representative of Southern countries and emerging powers. Turkey is the only Islamic country in the Middle East who has successfully carried out modernization and secularization. It is advanced on technology level and moderation. Its economic strength is also leading. The influence of the "Turkish Model", represented by democratization and Islam, is expanding. Turkish has already been a shining "star" among emerging economies in the world with its improving comprehensive strength and regional influence. Outstanding economic development performance makes Turkey a recognized emerging industrial country. It has been listed in MIST, CIVETS, Next-11, VISTA and MINT as well as one of top 10 emerging markets and a rising star after BRICS. With the increasing of its economic strength and expanding of its economic demands, Turkey has become an important player in global economic system. Turkey is facing more cooperation and competition with other global powers and regional groups; hence, it has more outstanding and long-term demands for international economic coordination. Turkey's rise is taking place against the backdrop of the declining of the Western position and the rise of emerging countries. Turkey, whose strength has soared, asks to play a more important role in international affairs. Its leader publicly sought to redistribute current global orders. ${ }^{16}$ As an emerging country and a member of G20, which is rare among OECD members, Turkey's position has laid good foundation for playing a role as a bridge in regional and global economic development.

Definitely, groupment rises of emerging countries have more and more interactions with global economic governance. The highlighting of the position of G20 has provided important chance and platform for emerging countries to participate in global governance, which is of great economic and strategic significance to China's rise and peaceful development. Both China and Turkey are emerging countries. Turkish "Looking east" policy transition also focus more and more on developing relationship with emerging countries such as China, India. Therefore, Turkey is a country that China could put more efforts in enlarging economic and strategic cooperation with it on global level. Cooperation between China and Turkey, two emerging countries, will definitely contribute to global economic development and transition of global economic governance.

Turkish has important strategic position in surrounding areas and Eurasia geo-economic landscape

As is known to all, Turkey has always been described as the "bridge connecting Asia and the Europe", which shows its unique global geo-strategic position. Turkey has special economic relationship with the Europe and has close economic interactions with surrounding areas including the Middle East, Central Asia and Africa. It is the bridgehead for the outside world to enter the Middle Eastern, Central Asian and African market. Turkey has also played a role as the engine of the stability in the Middle East, the energy channel maintaining the economic independence of Central Asia, the driving force of the future development of Europe. ${ }^{17}$ Firstly, Turkey is a member of OECD countries and a quasi-member of European Union. It has close economic relationship with the Europe and signed the agreement of customs union. The trade between Turkey and Europe is free; hence, Turkey has been an important springboard for outside countries to enter European market as well as an important platform attracting global investment 
and trade communication. Due to its unique location advantage, the surrounding area of Turkey covers dozens of countries, 1.5 billion population, about $\$ 25$ trillion GDP and a huge market with $\$ 8$ trillion trade volume. Secondly, because of the special relationship between Turkey and Caspian region in Central Asia, Turkey has long viewed this region as the emphasis of its diplomacy. Besides enhancing political connection and cultural infiltration in this region, Turkey also focuses on economic, trade and energy cooperation with it. The foundation of the economic cooperation between Turkey and this region is quite good. Turkey has also entered Central Asia with the help of the international capital investing on Turkey, and played a role as a middleman for international capital to enter the Caspian region in Central Asia. ${ }^{18}$ Third, the importance of Turkey as a corridor and hub in Eurasian energy transportation is increasingly outstanding. About 73 percent of global oil reserves and 72 percent of natural gas reserves are in Caspian region, the Middle East and Russia. Turkey locates exactly in the central area between supply and demand sides. ${ }^{19}$ Turkey is increasingly at the crossroads of the world energy trade. ${ }^{20}$ Turkey has actively promoted plans of energy corridor. Many oil and gas pipelines, which go from Caspian region, the Middle East and Russia to Europe, pass through Turkey. Turkey has been the vital country in operation of Eurasian oil and gas resources and maintaining of regional energy security. Its position in regional and in global economic system has been improved a lot.

Eurasia, where important established powers, important emerging powers and developed powers gather, is the center of global geopolitical stage and geopolitical changes in the global economic landscape. Turkey is a Middle Eastern country, a member of NATO, a quasi-member of European Union as well as a Turkic-speaking country that has close relationship with Central Asia. The trinity of the Middle East, Europe and Central Asia is unique, and these three regions are all of important practical significance to China. ${ }^{21}$ Currently, China starts to put efforts in Eurasia, trying to get ahead of others in future geo-political and economic competition. Turkey is a key node in concocting Eurasia. It plays important role in changes of economic landscape of Eurasia, and a strategic cooperative partner through which China could promote the westward of its economic strength and communicating with Eurasia.

\section{Turkey's position is strategically important in building Silk Road Economic Belt}

The building of the Silk Road Economic Belt meets strategic demands and economic development strategies of both China and Turkey. It brings new development opportunities to economic cooperation between the two. Silk Road Economic Belt represents the new idea and new framework of China's strategic operation toward Eurasia including the Middle East and Europe. It is an important part of China's strategic layout in Eurasia, which is of great economic and strategic significance. The building of the Silk Road Economic Belt also meets the strategic and economic demands of Turkey. In recent years, Turkey raised its ambitious development plan and foreign policy. However, due to limitation of its comprehensive national strength, its ambition as a power has been restricted. The increasing of China's national strength and the launching of the Silk Road Economic Belt strategy brings opportunities for Turkey to enhance its position with the help of China's power. Both central and local governments have great passion in building the new Silk Road, holding that Turkey's location advantage can be taken and Turkey's economic development can be promoted. As early as in 2011, China and Turkey have signed the Memorandum of Understanding on developing the New Silk Road. The Caspian region in Central 
Asia, which building of the Silk Road Economic Belt should firstly focus on, is of significance to both China and Turkey. Building this region into a prosperous and peace place is the common interests shared by both. The building of the Silk Road Economic Belt is the important chance to promote stable development of the Caspian region in Central Asia, as well as an important chance for China and Turkey to cooperate with the other and play bigger role on international stage.

With its advantages in many fields, Turkey has an important strategic position in China's promoting the building of the Silk Road Economic Belt. Firstly, Turkey's geo-political and geo-economic position is unique. It is naturally to be China's cooperative partner and the key bridge in building Silk Road Economic Belt in Eurasia. Secondly, Turkey's economic strength is relative strong. It has close economic and cultural connection with Caspian region in Central Asia and the Middle Eastern countries. It has also quite powerful strength in regional investment and development, which makes it an unignorable participant in building Silk Road Economic Belt. Thirdly, with its close economic connection with the Europe, Turkey becomes the transit point between the Europe and the outside world and the important support of the realization of the long-term version of Silk Road Economic Belt. Turkey is among the key channels of the development of future Silk Road extending to the Europe. It is vital in bringing out the prospect of the Silk Road from the Pacific Ocean to the Baltic Sea. ${ }^{22}$

\section{Constructions of the Sino-Turkish Strategic Economic Relationship}

Comprehensively speaking, the strategic cooperative relationship between China and Turkey has more policy and practical foundation in economic regard. In China's rise and participation in the Middle East, Eurasian and the transition of global economic pattern, China should attach more importance to Turkey's economic position and put efforts in building strategic economic relationship with it.

\section{Reinforcing Sino-Turkish economic cooperation fields}

First, transportation infrastructure is the most promising cooperation field for China and Turkey. As the traffic artery in Eurasia, Turkey has a grand vision of its domestic well-developed transportation network construction. It increased investment in highway and rail transport, the total investment is estimated as high as $\$ 350$ billion. It has also actively docked its infrastructure development with China's plan of building the Silk Road Economic Belt. Both sides share common interests on constructing a $4500 \mathrm{~km}$-long land transport route from China to Turkey passing through the Central Asia, with the hope to set up a modern Silk Road connecting the Europe and Asia. Many domestic programs on railways, tunnels and cross-border rails in Turkey have been viewed as a part of the Silk Road Economic Belt to get through Central Asia and Europe. The east-west railway program in Turkey is among the most mature and most promising projects along the Silk Road.

Second, mutual investment between China and Turkey and their investments on other countries are of great potential. China's expanding the investment on Turkey promotes Chinese enterprises' going outside, and also helps to ease the tension of unbalance in bilateral trade. Turkey can better play a role as the economic bridge connecting the Europe and Asia then. Turkey is an emerging power with shortage of funds, low domestic savings rate and high degree of external capital dependence. China's FDI was \$ 90.1 billion in 2013 while only about \$200 
million in it is on Turkey, accounting only 0.2 percent. After the promulgation of the Foreign Direct Investment Law, Turkey also introduced the new investment incentives scheme to improve investment environment in 2012. Turkey has big shortage of funds in domestic construction. Pushed by limited domestic funds and the outflow of Western funds, Turkey has been hoped to strive for China's investment to balance and enhance bilateral economic relationship, trying to make itself China's base camp to do business in the Middle East and Europe. Coupled with its broad neighboring markets, there are good prospects of China's investments on Turkey and Turkey's neighboring markets.

Third, international energy development and project contracting are main fields for China and Turkey to expand economic cooperation. Turkey has committed to make itself the energy hub in Eurasia, which brings important opportunities to energy development cooperation in Turkey, Caspian region in Central Asia and the Middle East. Both China and Turkey have carried out energy cooperation and built oil and gas pipelines with Caspian countries. Many views hold that China and Turkey have competition in this regard. ${ }^{23}$ In fact, however, there's no deep-rooted conflict. Both China and Turkey have expectation on getting through the Eurasia energy channel. Existing east-west energy pipelines have already laid foundation for the construction and connection of energy pipelines in wider range. Enterprises from two countries have also carried out energy development cooperation in some Middle East countries including Iraq; perhaps the cooperation will cover other places such as other countries in the Middle East and Africa in future. The economic growth of rising powers relies on its overseas market and resources to a large extent. For this reason, their economic contacts with developed countries are increasingly strong.

${ }^{24}$ Both China and Turkey are emerging powers that have growing close economic contacts with Asian and African countries, as well as the important contracting powers on global stage. If they can carry out effective cooperation on engineering contracting and form new cooperative model, intensify competition between two countries in the Middle Eastern and African market will be eased largely.

Fourth, both sides should continuously expand the cooperative fields. Besides further take the advantage of complementarity and enhancing mutually beneficial cooperation on transportation and communication, they should also actively explore the feasibility of expanding cooperation in fields including finance, renewable energy, high technology and mining, and find new growth point of practical cooperation. Meanwhile, methods, such as establishing foreign trade, economic cooperation zones and science and technology industrial park, can also been considered. For instance, mutual establishment of branches of bank and financial institutions could promote the rapid development of the cooperation on currency swap, local currency settlement of bilateral trade, China's buying government bonds of Turkey and financial field, and provide strong financial support to cooperation in infrastructure and investment and financing in other fields.

\section{Resolving economic conflicts and risks in Sino-Turkish economic relationship}

First, pay attention to and make every effort to resolve the trade unbalance and economic competition between China and Turkey. As two industrial emerging powers, China and Turkey has industrial structural overlap and international competition in manufacturing industries such as the textile sector. Also, because of the freedom of trade between Turkey and European Union, Chinese enterprises' entering Europe through Turkey could bring impacts to Turkish economy 
industry and even continuous trade deficit, which may worsen the unbalance in bilateral trade. The frictions and tensions in economic and trade relationship between China and Turkey have been intensified. Turkey is among the countries who have initiated most anti-dumping investigations toward China. The game, competition and coordination demands in economics and trade between two countries have shown a structured and protracted trend, which will threat the strategic economic relationship between the two. Besides the existing import restrictions on quota or quantity of products such as china, textile and apparel, till the end of 2013, 63 anti-dumping investigations general safeguard investigations and 6 special safeguard investigations have been launched by Turkey toward China. ${ }^{25}$ In almost every meeting, trade deficit is the unavoidable topic to leaders from both sides. China should attach importance to Turkish concerns, trying to resolve the problem.

Second, actively enhance strategic economic mutual trust between the two and try to reduce external interference. Because of the trade unbalance, competition in export market, fighting for influence in Caspian region in Central Asia and confounding factors including the Xinjiang affair, lack of strategic mutual trust also stand in the way of Sino-Turkish economic relationship. Besides their own problems, mutual trust between China and Turkey has also been impacted by the U.S. and the Europe. As a member of NATO and a quasi-member of the European Union, developing relationships with the U.S. and the Europe are two pillars of Turkish diplomacy. All the time joining the European Union is Turkish established strategy. Turkey has long been a member of the Western international community and the Westernization/Europeanization processes continue to shape Turkey's ongoing identity transformation. ${ }^{26}$ Against such backdrop, the strategic mutual trust between China and Turkey will unavoidably be impacted by the Sino-U.S. and Sino-European relationships. For instance, the U.S. and Europe has interfered China's investment, high-tech cooperation and arms sales on Turkey in various degrees. The question that how to reduce the interferences from the outside, especially the West, and strengthen the independence in diplomacy in future, is the important content of the strategic economic mutual trust between the two countries.

Third, prevent from the risks in Sino-Turkish economic relationship. First of all, the risks in Turkish macroeconomic performance, especially the turbulence in financial market, should be noticed. The structural problem in Turkey's own economics is quite prominent. It has high dependence on foreign funds, and is easily be impacted by fluctuations of the economic situation in outside world. Because of the fragility of the strategy of high international borrowing and current-account deficit, the financial crisis emanating from the USA hit Turkey at a time when its growth model was based on exports and external financing. ${ }^{27}$ In recent two years, the economic growth of Turkish economic has declined, the outflows of funds have worsened, currency depreciation has been increasingly significantly and economic risks have increased. Secondly, non-economic risks, like domestic political disputes and political instability, should not be ignored. Although the political situation in Turkey is quite stable, there are still disputes between different political parties and between secular and religious forces, as well as problems such as military interference in domestic affairs and secessionists. Finally, Turkey's disputes with its neighboring countries and the impact of the turbulence in the Middle East should also be paid attention. In recent years, the great changes in the Middle East and Turkey's Middle East policy make the surrounding environment of Turkey get worse. Problems such as refugees, terrorism and separatism can be found within the territory of Turkey. 


\section{Improving the importance of Sino-Turkish strategic economic relationship}

First, China should make the economic relationship as the cornerstone of the bilateral strategic cooperative relationship, and make Turkey among the strategic pivot countries with global significance. There are three foundations of the strategic cooperative relationship between China and Turkey: political consensus of jointly rise and roles as powers, security demands (especially that Turkey is important to China's neighboring security environment) and growing bilateral economic and trade relationship. Among them, economic cooperation is the most fundamental in bilateral strategic cooperative relationship. Provided the key position in Eurasian geopolitics and geo-economics, influential economic strength, participating capability of Turkey and its "looking east" policy, the improvement of the Sino-Turkish economic relationship will be helpful to enhance the independence of Turkish politics, economics and diplomacy and further make Turkey China's strategic economic cooperative partner. By then, the competition between the two countries will be on the sound development track and the establishment of "One Belt One Road" and the China's changes in Eurasia geo-economic landscape will gain more supports.

Second, enrich the multiple cooperative and communication mechanisms, including both government-to-government and people-to-people, between the two countries, establish strategic economic dialogue mechanism and safeguard the smooth development of the Sino-Turkish strategic economic relationship. Communications and contacts in many levels have been maintained between the two countries. They have established various cooperative mechanisms, such as the annual consultation mechanism of the economic and trade commission, China-Turkey Trade and Investment Cooperation Forum, China-Turkey Cooperation Forum and China-Turkey Business Forum. In future, they should further enhance the coordination and exchange mechanism in all-range levels, especially in fields such as important trade sector in manufacturing, engineering construction investment projects, banking and finance institutions and trade friction-prone fields, so as to guarantee the development and improvement of Sino-Turkish economic relationship.

Third, Turkey is the important target for Chinese enterprises to "going outside". Hence, more efforts should be put in deep analysis on Turkish market. Turkey has provided many chances of investment and development for Chinese enterprises in regards of infrastructure construction, resource development, project operation and technical cooperation. However, Chinese enterprises always lack the research on external market and targeted enterprises. Most of the times, the information from the related investment promoting agencies or research institutions has just introduced the country's investment environment and general polices instead of detailed analysis. Chinese government, universities and research institutions, especially the chambers of commerce, should learn from the foreign countries and carry out institutionalized, regular and systematic research on related industries, business and market environment of Turkey, so as to make targeted plan to improve the bilateral economic cooperation at a high level.

\section{Conclusion}

This article has demonstrated that development of Sino-Turkish economic cooperation and fruitful contents of bilateral strategic economic relationship, and tried to give some comprehensive 
suggestions to build this mutually beneficial relationship in the future. Despite the scale of the bilateral economic relationship between the two countries is far from strategic, Turkey is of multiple strategic importance in economic respective for China. It is the sustainable bilateral economic cooperation that forms the foundation of the strategic relationship between China and Turkey in new era.

Turkey's economic scale and international position have dramatically increased in recent years, it is presumed to be one of rising powers, and the dynamics of Turkey's rising has attracted more and more attention in the world. In the context of global pattern changes and groupment rising of emerging powers, China and Turkey, which locates at the two ends of the Eurasia, share similar ambitious goals and developing targets. Common interests of the two are increasing and the demands for strategic and economic cooperation are also growing. On the way of jointly rising, China and Turkey can found more meeting points of interests and opportunities for cooperation. Hence, the establishing of the Sino-Turkish strategic economic relationship should be placed on the agenda for both. It is the economic strength and rising trend of the two countries that makes the further bilateral economic and trade cooperation with great potential. As two emerging powers, they have more chances for strategic cooperation in global economic transition and governance. Turkey plays an important strategic role in the changes of Eurasia geo-economic landscape and the establishment of the Silk Road Economic Belt. The Sino-Turkish strategic economic relationship has the rich connotation. It has strategic value and space in many fields including trade, investment, finance and global economic governance, in levels such as bilateral level, the Middle East, the Eurasia and even the global level. In future, economic cooperation between the two should be enhanced in transportation infrastructure, investment and financial fields, international project contracting and international energy development. Both sides should joint together in properly dealing with the economic disputes and risks, and putting efforts in building the new type of Sino-Turkish strategic economic relationship which is inclusive, symbiotic and mutually beneficial.

\section{Acknowledgments}

This article is the preliminary-stage achievement of a research program of the Key Research Base for Humanity and Social Sciences established by China's Education Ministry (2014JDZDSZX002), a research program funded by China's National Fund for Social Sciences (14BGJ008), a youth research team project funded by Shanghai International Studies University.

Dr. Zhiqiang Zou is currently Assist. Prof. in the Middle East Studies Institute of Shanghai International Studies University, Shanghai, China.

\section{Notes}

\footnotetext{
${ }^{1}$ Zan Tao, "An Alternative Partner to the West? Turkey's Growing Relations with China", Middle East Journal, OCT 25, 2013.

2 Zan Tao, "Sino-Turkish Relationship and Turkey's Thoughts on China's Rise", Arab World Studies, $2010(4)$, p. 65.

3 Svante E. Cornell, “What Drives Turkish Foreign Policy?” Middle East Quarterly, Winter 2012, p.17.
} 
${ }^{4}$ Ding Gong," Deep Roots for Turkey's Rise and Its Influence to Future Trends", World Economics \& Politics, 2013(1), p.62.

${ }_{6}$ Turkish Statistical Institute (TurkStat), http://www.turkstat.gov.tr/ (accessed October 18, 2014) WTO Statistics

Database, http://stat.wto.org/CountryProfile/WSDBCountryPFView.aspx?Language=E\&Country=TR (accessed July 22, 2014)

7 Turkish Statistical Institute (TurkStat), http://www.turkstat.gov.tr/Start.do (accessed October 18, 2014)

${ }^{8}$ Mehmet Ozkan, "Does 'Rising Power' Mean 'Rising Donor'? Turkey's Development Aid in Africa", Africa Review, 2013, Vol. 5, No. 2, p.142.

9 Tom Wheeler, "Ankara to Africa: Turkey's Outreach since 2005", South African Journal of International Affairs, Vol. 18, No. 1, April 2011, p.59.

${ }^{10}$ Wang Zhen, "New Development of Turkey's Economic and Trade Strategies and Sino-Turkish Economic and Trade Relationship", World Economy Study, 2008(11), p.70.

${ }_{11}$ Turkish Statistical Institute (TurkStat), http://www.turkstat.gov.tr/Start.do (accessed October 18, 2014)

12 Chinese Ministry of Commerce, China's Foreign Trade Report ( 2008-2014) , http://gpj.mofcom.gov.cn/article/d/cw/ (accessed October 22, 2014)

13 Ding Gong, "Turkish Strong Rise and Its Impacts on Geo-politics in the Middle East", West Asia and Africa, 2013(3), p.95.

${ }^{14}$ Yilmaz Argüden, "An Overview of the Turkish Economy: Outlook and Current Perspectives", Middle East Policy Briefs, No.4, Dec. 2007. p.8.

15 Ding Gong, "40 Years of Sino-Turkish Relationship: Yesterday and Tomorrow", Arab World Studies, 2011(3), p.20.

${ }^{16}$ Tarık Oğuzlua \& Emel Parlar Dal, "Decoding Turkey's Rise: An Introduction”, Turkish Studies, 2013, Vol. 14, No. 4, pp. 617-636.

${ }^{17}$ Y lmaz Argüden, "An Overview of the Turkish Economy: Outlook and Current Perspectives", Middle East Policy Briefs, No.4, Dec. 2007. p.1.

${ }^{18}$ Xie Wenxin, "The Influence of Islam in Central Asia and China's Countermeasures in Central Asian Energy Cooperation", Journal of Hui Muslim Minority Studies, 2012(3), p.80.

19 Business chamber of Chinese Consulate General in Istanbul, "Turkey works to strengthen the construction of energy corridors". http://istanbul.mofcom.gov.cn/article/jmxw/201312/20131200413822.shtml (accessed October 15, 2014)

20 Tuncay Babali, "Turkey at the Energy Crossroads: Turkey, Present and Past", Middle East Quarterly, Spring 2009, p. 25.

${ }^{21}$ Xiao Xian, "Establishing New Type of Sino-Turkish Strategic Cooperative Partnership", West Asia and Africa, 2011(9), p.24.

${ }^{22}$ See Zou Zhiqiang, "Silk Road Economic Belt and Sino-Turkish economic and trade relationship", Journal of Hui Muslim Minority Studies, 2014(2), p.128.

${ }^{23}$ John C. K. Daly. "Sino-Turkish Relations Beyond the Silk Road". China Brief, Volume 7, Issue 4, May 9, 2007.

${ }^{24}$ Mehmet Ozkan, “Does 'Rising Power' Mean 'Rising Donor'? Turkey’s Development Aid in Africa”, Africa Review, 2013, Vol. 5, No. 2, p.139.

25 Chinese Ministry of Commerce , China's Foreign Trade Report ( 2014 ). http://gpj.mofcom.gov.cn/article/d/cw/ (accessed October 26, 2014)

${ }^{26}$ Tarık Og uzlu, “Making Sense of Turkey’s Rising Power Status: What Does Turkey’s Approach within NATO Tell Us?" Turkish Studies, 2013, Vol. 14, No. 4, p. 774.

27 Zülküf Aydın, "Global crisis, Turkey and the regulation of economic crisis", Capital \& Class, 2013, 37(1), p.96. 